\title{
EFFECTIVE CONSENT TO SEARCH AND SEIZURE
}

The fourth amendment, by providing that there shall be no unreasonable searches and that no warrant shall issue but on probable cause, ${ }^{1}$ guarantees that some sphere of an individual's privacy will be kept free from an invasion by police officers. ${ }^{2}$ Since the amendment is for the individual's own protection, once he effectively consents to a search the resultant invasion of his privacy is not unconstitutional. A "consent," then, is a legal term representing the conclusion that an individual has waived his fourth amendment right.

Traditionally, courts have closely scrutinized situations where individuals have allegedly waived their constitutional rights. In Johnson $v$. Zerbst, ${ }^{3}$ a waiver of counsel case, the Supreme Court stated:

It has been pointed out that "courts indulge every reasonable presumption against waiver" of fundamental constitutional rights and that we "do not presume acquiescence in the loss of fundamental rights." A waiver is ordinarily an intentional relinquishment or abandonment of a known right or privilege. ${ }^{4}$

The clear implication of this expression is that not every instance in which an individual has permitted a search will be held by the courts to have been an effective waiver of his constitutional rights. Therefore, it becomes necessary to designate some characteristics of the consensual situation to provide a basis for determining which consents are to be regarded as effectively waiving the fourth amendment protection.

\section{Theoretical Considerations}

\section{A. Effective Consent}

"Consent" cannot be determined merely by reference to the customary implications of the word. It is unrealistic to assert that the giving of consent means that the consenter "wants" the officer to conduct a search of his premises, for few people would affirmatively desire, in an absolute sense, to have a policeman looking through their property. ${ }^{5}$ Similarly, it is not

1 U.S. Const. amend. IV.

2 See generally Davis v. United States, 328 U.S. 582, 594 (1946) (Frankfurter, J., dissenting); Commonwealth v. Dana, 43 Mass. (2 Met.) 329 (1841) (construing Massachusetts Bill of Rights); 10 AdaMs Works $247-48$ (description of James Otis' speech on writs of assistance) ; Lasson, The History and Development of the Fourth Amendment to the United States Constitution, 55 JoHns Hopkrns UNIVERSITY Studies in Fistorical and Political Studies 211 (1937).

3304 U.S. 458 (1938).

4 Id. at 464.

5 Cf. Judd v. United States, 190 F.2d 649, 651 (D.C. Cir. 1951) : "true consent, free of fear or pressure, is not so readily to be found." 
enough to ask whether, in consenting, an individual "chooses" to have a search, for even preference for a search over exposure to a policeman's nightstick represents some form of choice. Clearly, then, a ruling that a particular consent is or is not an effective waiver of a constitutional protection involves a judicial determination that the reasons why the individual chose to allow a search were either acceptable or unacceptable. Under this approach the courts should focus upon that which the individual obtains in exchange for his consent.

There is no ready yardstick by which one can measure the acceptability of the reasons for an individual's choosing to acquiesce in a search. The courts are forced into the supervisory role of ensuring some minimal amount of integrity to the choice-making of individuals who purport to surrender their constitutional protections. Whether a particular reason for a consent is held to be unacceptable will therefore reflect the court's conception of the range of choice to which an individual is entitled before waiving his fourth amendment rights.

\section{B. The Exclusionary Rule}

The Supreme Court has adopted a rule excluding from trial certain evidence obtained by police officers to safeguard individuals' fourth amendment rights. ${ }^{6}$ The most widely accepted rationale for this rule has been its deterrence of undesirable police conduct ${ }^{7}$-more specifically, that conduct which is thought most likely to imperil individuals' constitutional rights. Strictly applying this rationale, if police conduct in a particular case is not thought likely to lead to ineffective consents, the evidence would not be excluded, even if the defendant's consent was in fact ineffective. Correspondingly, evidence would be excluded when police conduct is highly likely to induce ineffective consents, even though the consent in the particular case was effective.

The rule which would provide maximum deterrence of searches following ineffective consents would be one which excludes all evidence stem-

6 Weeks v. United States, 232 U.S. 383 (1914). The Supreme Court applied the exclusionary rule to the states through Mapp v. Ohio, 367 U.S. 643 (1961), and Ker v. California, 374 U.S. 23 (1963). See Stoner v. California, 376 U.S. 483 (1964), for an application of the exclusionary rule by the Court in a state consent to search case.

7 See Mapp v. Ohio, supra note 6, at 656; Elkins v. United States, 364 U.S. 206, 217 (1960); Blakey, The Rule of Amonncement and Unlazoful Entry: Miller v. United States and Ker v. California, 112 U. PA. L. Rev. 499, 552 (1964).

Another rationale for the rule is that it is a violation of a defendant's right against self-incrimination to use against him evidence seized in violation of the Constitution. See Mapp v. Ohio, stepra note 6, at 661 (opinion of Black, J.). This rationale is criticized in Bender, The Retroactive Effect of an Overruling Constitutional Decision: Mapp v. Ohio, 110 U. PA. L. Rev. 650, 664-68 (1962).

An earlier rationale for the rule was to keep tainted material out of the courts. See Olmstead v. United States, 277 U.S. 438, 471, 485 (1927) (Brandeis, J., dissenting); id. at 469-70 (Holmes, J., dissenting). This rationale is criticized in Amsterdam, Search, Seizure, and Section 2255: A Comment, 112 U. PA. L. REv. 378, 389 n.49 (1964). 
ming from searches made without a valid warrant. ${ }^{8}$ The police conduct required by such a rule is clear, and if obeyed, there would be no searches in violation of the fourth amendment. However, the cost of such a rule would be great. Search warrants would have to be obtained in cases where the suspect would prefer an immediate search to the possibility of a future search under a warrant. A search in such cases would not violate the constitutional requirements and would be advantageous to both the suspect and the police. Under a no-consent rule, the law-abiding officer would either get a search warrant or continue to investigate the suspect in other ways, which could involve considerable annoyance and inconvenience to the suspect, his friends, and acquaintances. However, if the search could take place immediately, the policeman might be sufficiently convinced of the suspect's innocence to forestall further investigation, and, by eliminating one suspect, the police would be able to move closer to the solution of the crime. Furthermore, similar considerations are operative even where there is incriminating evidence, for the suspect may still have acceptable reasons for allowing a search; but the above rule would have the effect of eliminating such searches.

An exclusionary rule should be adopted which achieves the optimum balance between deterrence of constitutional deprivations and social costs incurred. ${ }^{2}$ Therefore, the rule for determining effective consents to search should produce a sufficient deterrence of official conduct which induces unacceptable waivers of fourth amendment rights and at the same time retain as much as possible the advantages of allowing individuals to consent to a search.

\section{Consents to Search}

\section{A. Coerced Consents}

The generic term describing a great number of situations in which consents are given for unacceptable reasons is that the consent was "coerced." 10 A flagrant example is when the police induce in the suspect a fear of physical harm if consent is not given. This type of choice is sharply contrasted to that given in exchange for some hoped-for advantages in future relations with the police. For instance, an effective consent may be given even when the the suspect knows that incriminating evidence will be found. The suspect may believe that the evidence will undoubtedly be found at a future time-for example, where a large still is located in the suspect's cellar-and he may therefore wish to make the best of his embarassment by an attitude of cooperation.

It is apparent that the latter type of choice is far less appropriate as an object of judicial concern than is the former. However, these two choices

8 Higgins v. United States, 209 F.2d 819 (D.C. Cir. 1954), approaches this position.

9 An exclusionary rule is a "medicament" of which "no more should be swallowed than is needed to combat the disease." Amsterdam, supra note 7 , at 389 .

10 See, e.g., Amos v. United States, 255 U.S. 313 (1921). 
illustrate the spectrum within which the courts must operate in handling the problem of coercion. Once it is decided that a particular type of choice is unacceptable, the task becomes one of formulating rules which will reduce the possibility that suspects will choose a search for such reasons. Unfortunately, the courts have tended to be preoccupied with the exigencies of the cases ${ }^{11}$ before them and have been less than articulate in resolving the broader issues of whether and why particular choices are unacceptable waivers of constitutional rights.

Courts have taken two approaches in attempting to minimize the number of coerced consents. Under the first, the court attempts to determine whether the suspect's consent to a search was in fact uncoerced. This subjective approach can be characterized as a post hoc effort to reconstruct the suspect's state of mind at the time the consent was given.. ${ }^{12}$ The second approach is objective in that it requires a determination of whether the police have acted in a way which would probably coerce an average person in the suspect's apparent position. Under this approach, it is the police conduct rather than the suspect's mental state which is the focus of judicial attention.

While these approaches would not seem to provide an appreciably different deterrent effect on police officers, ${ }^{13}$ the objective approach is nevertheless preferable. Under the subjective approach, the factual issue of whether the suspect's consent was actually coerced must be litigated in every case. Under the objective approach, a court need only measure the police conduct in a particular case against the standard of conduct which already has been determined to be likely to coerce an average suspect.

The objective approach would not only ameliorate a trial court's difficulties in deciding cases, but would also increase the extent of appellate review. Thus, if a trial court has decided that a particular defendant's consent was not coerced, it is difficult for an appellate court to find this factual determination erroneous. On the other hand, if a trial court finds that an officer has acted in a particular way and then finds that this conduct was not the type which would be likely to coerce an average suspect, the appellate court can evaluate as a matter of law whether or not the officer's conduct was the kind which should be deterred. ${ }^{14}$

11 Courts often iterate that each consent to search case must be decided on its own particular facts. See, e.g., Davis v. United States, 327 F.2d 301, 306 (9th Cir. 1964); United States v. Zeimer, 291 F.2d 100, 103 (7th Cir. 1961), cert. denied, 368 U.S. 877 (1961).

12 See Application of Tomich, 221 F. Supp. 500 (D. Mont. 1963), aff'd, 332 F.2d 987 (9th Cir. 1964); United States v. Gregory, 204 F. Supp. 884 (S.D.N.Y. 1962).

13 If consents are invalidated only when the court believes that they were actually coerced, officers would tend to act in a way which would not coerce the suspect at hand. This conduct would probably be that which would not coerce an average person in the suspect's position. Thus both the subjective and objective approaches would tend to deter officers from the same kind of conduct.

14 Where constitutional rights are involved, it is particularly appropriate for the appellate courts to assert control over the trial court. The appellate courts are removed from the passions of the trial and are therefore better able to administer the exclusionary rules objectively in litigated cases. 


\section{Facts Warranting a Finding of Coercion}

Catalanotte $v$. United States ${ }^{15}$ presents a striking illustration of the kinds of facts which operate to deprive the suspect of any meaningful choice. Eleven officers came to the suspect's house at night. Five armed officers went to the door, entered the house, and, in the presence of the suspect's wife and paralyzed daughter, asked the suspect whether he had any narcotics in the house. The officers then physically restrained the suspect while he was revealing the contents of his pockets, and shortly after this the suspect told the officers, "The house is yours." The court held the consent ineffective. The number of officers, their aggressive manner, the time of night, and the presence of the suspect's dependents all testify to the high probability of intimidation. ${ }^{16}$

In United States $v$. Arrington, ${ }^{17}$ the court invalidated a consent to search given by a suspect who was under arrest and in jail with no charge against him. In this situation it is probable that the suspect's isolation will induce considerable fear and uncertainty which might lead him to choose a search in order to avoid unseen dangers. It seems justifiable under such circumstances to hold that the suspect chose to allow the search for unacceptable reasons.

Of course a suspect in jail might choose to allow a search because of a hope that it would lead to his exculpation, and such a reason seems to be an acceptable one. This possibility is discounted somewhat by the likelihood that a suspect aware of the prospects of exculpation would be likely to request a search before being jailed. In fact even if suspects in jail choose searches for such an acceptable reason the potential danger that many of them would do so for unacceptable reasons is of sufficient magnitude to justify a rule that a suspect in jail cannot consent to a search..$^{18}$

In Farris $v$. United States, ${ }^{19}$ an officer first announced to the suspect that he was going to conduct a search, and the suspect then consented. The officer's forceful manner seemed to leave the suspect with no real alternative

15208 F.2d 264 (6th Cir. 1953).

${ }^{16}$ See United States v. Rutheiser, 203 F. Supp. 891 (S.D.N.Y. 1962) (consent invalid when given after agents entered suspect's house at night and confronted him in front of his family); United States v. Marguette, 271 Fed. 120 (N.D. Cal. 1920), aff'd, 271 Fed. 214 (9th Cir. 1921) (consent invalid when given after officers came to door armed with shotguns demanding admission). But see Martinez v. United States, 333 F.2d 405 (9th Cir. 1964) (consent persistently sought in the presence of suspect's unnerved wife held valid); United States v. Martin, 176 F. Supp. 262 (S.D. N.Y. 1959) (consent valid when given after three officers approached suspect in the daytime at his place of business).

17215 F.2d 630 (7th Cir. 1954).

18 See Channel v. United States, 285 F.2d 217 (9th Cir. 1960) (suspect in custody of federal officers); Judd v. United States, 190 F.2d 649 (D.C. Cir. 1951) (suspect in jail under police interrogation). A consent following a valid arrest has also been held ineffective. See Montana v. Tomich, 332 F.2d 987 (9th Cir. 1964); Gregory v. United States, 204 F. Supp. 884 (S.D.N.Y. 1962). But see Gendron v. United States, 227 F. Supp. 182 (E.D. Mo. 1964); United States v. Klaw, 227 F. Supp. 12 (S.D. N.Y. 1964).

18 See Farris v. United States, 24 F.2d 639 (9th Cir. 1928). 
but to choose a search. It is highly improbable that an average suspect would assert his opposition to a search which, to all appearances, was inevitable. The court was therefore correct in holding this consent ineffective. ${ }^{20}$

In Takahashi v. United States, ${ }^{21}$ the court invalidated a consent given to an officer by a Japanese-American during World War II. This suspect was manifestly of a class that would be likely to follow police suggestions because of fear. In such a case even routine police conduct would have a high probability of coercing a consent; therefore, a court would be justified in invalidating almost any consent to a search. ${ }^{22}$

\section{Facts Waranting a Finding of Noncoercion}

In Honig v. United States, ${ }^{23}$ one federal agent and two police officers went to the suspect's room. After being invited to enter, the officers informed the suspect of the complaint against him and asked him for identification. When he answered that he had none, the officers asked if he would mind if they searched the room for identification, and he told them to proceed. The court held this to be an effective consent. In this situation the officers' actions seemed sufficiently polite and unobtrusive to render it unlikely that the average man in the suspect's position would be choosing a search for unacceptable reasons.

In other cases courts have asserted that a consent to search is effective because a suspect has rendered affirmative assistance to a police officer. ${ }^{24}$ Under the objective approach, a suspect's affirmative assistance should be crucial only if it occurs before the police officer takes any action which might be considered undesirable. ${ }^{25}$ If the suspect takes the initiative in allowing a search, it is very likely that acceptable reasons have led him to choose to allow the search.

20 See United States v. Slusser, 270 Fed. 818 (S.D. Ohio 1921) ; cf. Lee v. United States, 232 F.2d 354 (D.C. Cir. 1956) (consent invalid when obtained after uninvited officer walked through open door). Compare McDonald v. United States, 307 F.2d 272 (10th Cir. 1962) (consent valid when obtained after officers told arrested suspect they were going to conduct a search and asked him if he had any objections).

21143 F.2d 118 (9th Cir. 1944).

22 See Kovach v. United States, 53 F.2d 639 (6th Cir. 1931) (burden of proving an effective consent heavier when the suspect does not readily speak or understand English); United States v. Wai Lau, 215 F. Supp. 684 (S.D.N.Y. 1963) (consent invalid when given by suspect unable to speak English with any facility).

23208 F.2d 916 (8th Cir. 1953).

24 See United States v. Smith, 308 F.2d 657, 664 (2d Cir. 1962) (dictum), cert. derried, 372 U.S. 906 (1963) ; United States v. MacLeod, 207 F.2d 853, 856 (7th Cir. 1953) (dictum).

In Snith the suspect was validly arrested and narcotics found in her possession. The police then asked her if she had more narcotics; she answered affirmatively and showed the police where they were located. This was held to be an effective consent. In MacLeod consent was held valid when, after some incriminating evidence was obtained, the suspect opened a chest for the police and brought them a printing press.

25 Where a suspect affirmatively helps the policeman after the policeman has acted in a coercive manner, the evidence should be excluded to deter such conduct even if the consent was not coerced. See text following note 7 supra. 


\section{The Middleground--Police Persistence}

In United States $v$. Ziemer, ${ }^{26}$ when two officers came to the suspect's apartment door and told him they were looking for a stolen suit of clothes, he became very nervous. One of the officers asked the suspect whether he would allow him to enter, and the suspect answered, "I would rather not." The officers persisted, telling the suspect that if he did not possess the clothing he would have nothing to hide. The court held the suspect's subsequent allowance of a search to be an effective consent.

In Pekar v. United States, ${ }^{27}$ federal agents came to the suspect's apartment and told him they wanted to talk with him. After a ten minute silence, the agents repeated their request. At the suspect's request, the agents shoved some identification under the door. Finally, the suspect opened the door, and the agents, upon entering, saw some luggage. When they asked the suspect's permission to inspect the luggage and search the room, the suspect said he did not mind. Upon finding incriminating evidence, the officers asked the suspect to sign a waiver of search warrant form, but he refused. ${ }^{28}$ The court held the consent to search invalid.

In both of the above cases the suspect at first declined to allow a search, but, after some persistence on the part of the officer, changed his mind. There are at least two possibilities to account for such behavior. The suspect may believe that the officer will not leave until he does consent. ${ }^{29}$ Alternatively, the suspect might merely have changed his mind about the search's desirability. The former seems an unacceptable reason for waiving one's rights, while the latter seems unobjectionable.

A court's decision as to whether officer persistence should be deterred should be grounded on the likelihood that this persistence will lead suspects to allow searches because they believe the officer will not leave until they do so. The court should make a value judgment as to whether this likelihood is sufficiently high to warrant deterrence of police persistency. A decision in favor of deterrence should be embodied in a rule that effective consent cannot be given once a suspect has refused to allow a search. ${ }^{30}$

28291 F.2d 100 (7th Cir.), cert. denied, 368 U.S. 877 (1961).

27315 F.2d 319 (5th Cir. 1963).

28 The court partially based its holding on the suspect's refusal to sign the waiver. Id. at 325 . However, since the objective approach focuses only on the officer's conduct before a consent to search is given, this factor should be relevant only to whether the officer was telling the truth. Compare note 25 supra.

29 Compare Martinez v. United States, 333 F.2d 405 (9th Cir. 1964) (consent valid although obtained after being persistently sought in the presence of the suspect's wife who was becoming upset).

$30 \mathrm{~A}$ similar kind of assessment should be made in other difficult consent to search cases. Compare United States v. McCarthy, 297 F.2d 183 (7th Cir.), cert. denied, 369 U.S. 850 (1962) (consent to be fingerprinted valid although given after federal officer warned suspect that if he did not do so the city police would probably take him into custody), with United States v. Baldocci, 42 F.2d 567 (S.D. Cal. 1930) (consent invalid when obtained after officer told suspect he would obtain a search warrant if the suspect did not consent to a search). 
In Ziemer and Pekar, instead of promulgating broad rules, the courts apparently plunged into the particular facts of each case. ${ }^{31}$ When an exclusionary rule is involved, however, the promulgation of broad and clear rules in order to minimize uncertainty for police officers is especially appropriate. An exclusionary rule will produce the optimal deterrent effect if the rule is clear enough that the officer will know precisely when evidence he obtains will be excluded. If the rule is unclear, a policeman will have no firm guidelines and will be more likely either to indulge in undesirable conduct on the one hand or refrain from desirable conduct on the other. ${ }^{32}$

\section{B. Shortcomings of the Current Tests \\ 1. The Problem of Knowing Waiver}

When a suspect allows a search, while confronted only with relatively mild police conduct, his choice would seem to be made for acceptable reasons. However, there are many cases of reportedly innocuous police conduct in which the suspect allowed a search which seems to be obviously contrary to his interests. ${ }^{33}$ In United States $v$. Gregory, ${ }^{34}$ the court made the following observation: "[T] he alleged consent under the facts and circumstances here presented-a defendant at once denying that narcotics are in his room and at the same time agreeing to a search which obviously must yield narcotics-is not in accord with common experience." 35 Since the situation described in Gregory seems to arise frequently, ${ }^{36}$ one can conclude only that a substantial number of suspects are choosing searches for reasons not apparent from the reported facts.

One possibility is that some suspects allow searches merely because they are ignorant of their right to refuse to allow them. Such a suspect should not be held to have effectively waived his fourth amendment right..37 There can be no "intentional relinquishment . . . of a known right" 38 until a person knows that the right exists. This knowledge is essential if the choice to permit a search is to be a meaningful one.

31 Ziemer states that each search and seizure case must be decided on the basis of its own particular facts. 291 F.2d at 103.

32 See Blakey, supra note 7, at 552 n.379.

33 See, e.g., Honig v. United States, 208 F.2d 916 (8th Cir. 1953) ; United States v. MacLeod, 207 F.2d 853 (7th Cir. 1953).

34204 F. Supp. 884 (S.D.N.Y. 1962), aff'd, 309 F.2d 536 (2d Cir. 1962).

35 Id. at 885. Compare Martinez v. United States, 333 F.2d 405, 407 (9th Cir. 1964) (dictum); People v. Burke, 47 Cal. 2d 45, 301 P.2d 245 (1956); People v. West, 144 Cal. App. 2d 214, 300 P.2d 729 (Dist. Ct. App. 1956).

36 See cases cited note 33 supra.

37 United States v. Roberts, 179 F. Supp. 478 (D.D.C. 1959). Many courts have said that a consent to search must be intelligently given. See, e.g., United States v. Smith, 308 F.2d 657, 663 (2d Cir.) (dictum), cert. denied, 372 U.S. 906 (1963); Judd v. United States, 190 F.2d 649, 651 (D.C. Cir. 1951) (dictum).

38 Johnson v. Zerbst, 304 U.S. 458, 464 (1938). 


\section{a. A Rule of Disclosure}

In view of the above difficulties, police officers seeking consents to search should be required to inform suspects of their right not to be searched without a warrant. Thus, an officer might be required to say, "You do not have to consent to a search of your house, and without your permission, I cannot make any search without a search warrant."

In the analogous area of self-incrimination, the Supreme Court has held that a suspect before a United States Commissioner need not be warned that he has a right to remain silent. ${ }^{39}$ However, in United States v. Scully, ${ }^{40}$ a circuit court advocated a warning requirement, but declined to adopt it in the face of the adverse Supreme Court rulings. ${ }^{41}$ Thus, there is some judicial recognition of the need for a warning in the selfincrimination area. There is an equally strong need for a warning in the area of consent to search.

Whether a suspect can permanently prevent a search will depend upon whether the officer can show facts constituting probable cause for the issuance of a search warrant. Therefore, a suspect cannot fully assess the wisdom of allowing a search without knowing whether or not the officer can otherwise obtain a warrant. It would seem but an extension of the warning requirement to demand that the suspect also be informed whether a warrant could be obtained. However, to preserve the fourth amendment guarantee of privacy, it is necessary only to insure that one surrendering this protection has a meaningful choice, not that he make an optimal decision. Therefore, the officer should not be required to inform the suspect of the likelihood that a search warrant will be issued. ${ }^{42}$

\section{b. A No-Solicitation Rule.}

Another possible rule would be the disallowance of any consent to search which was solicited. Under this rule there could be no effective consent whenever an officer asked for permission to search. Such a rule would provide a significant fourth amendment safeguard and still retain the essential advantages of a consent to search rule. It is unlikely that an unsolicited individual would allow a search because he thought he lacked an alternative. If a suspect requests a search, it would seem that he is affirmatively choosing to allow one. ${ }^{43}$ If he does not want to allow the

39 See Powers v. United States, 223 U.S. 303 (1912) ; Wilson v. United States, 162 U.S. 613 (1896). However, dictum in Wilson suggests that if the defendant can prove that he did not know of his right to remain silent at the time he made a statement in response to a question, then his statement cannot be admitted against him.

40225 F.2d 113, 116 (2d Cir.), cert. denied, 350 U.S. 897 (1955).

41 See cases cited note 39 supra.

42 Courts have divided on the question of whether an officer may volunteer this information. See, e.g., United States v. Baldocci, 42 F.2d 567 (S.D. Cal. 1930) (consent given after officer said he would get a search warrant if suspect refused held invalid); Gatterdam v. United States, 5 F.2d 673 (6th Cir. 1925) (such facts held immaterial).

43 Compare text accompanying notes $24-25$ supra. 
search, he has the obvious alternative of saying nothing about it until the officer broaches the subject.

This rule would have the disadvantage of eliminating constitutionally permissible searches in situations where suspects who would effectively choose to allow a search would not venture to ask for one. However, this disadvantage is lessened by the likelihood that suspects anxious to clear themselves would request a search.

\section{c. An Evaluation of the Proposed Rules}

Both of the proposed rules would provide clearer standards of police conduct than do present consent rules. While a rule requiring a warning would leave a greater possibility of police coercion than would one prohibiting solicitation, ${ }^{44}$ the former would be less likely to curtail searches following choices made by suspects for acceptable reasons. Therefore, the warning rule is preferable and should be tried initially. If it then appears that officers are not effectively deterred from coercing suspects into giving consents to search, the no-solicitation rule should replace it.

\section{The Litigation Problem}

Neither of the two proposed rules would overcome the inability of the litigation process to uncover what actually transpired between the suspect and the police officer. Since triers of fact tend to believe officers rather than suspects, ${ }^{45}$ an officer willing to perjure himself could violate constitutional rights without imperiling evidence so obtained. ${ }^{46}$ The questioning of police officers by judges might be one means of meeting this problem. If it is believed that the litigation process still could not effectively expose the facts surrounding a consent, a rule would have to be adopted rendering ineffective any consent to search. ${ }^{47}$

\section{CONSEnt to Entry}

Police entry into a dwelling can be a form of search, but raises addition issues regarding effective consent. Problems involving the identity either of the person seeking to invade another's privacy or of the person consenting to such an invasion are more likely to arise in the entry context

44 With the first rule, the ordinary coercion rules could not be discarded; with the second, they are no longer necessary.

45 See, e.g., United States v. De Vivo, 190 F. Supp. 483, 485 (E.D.N.Y. 1961); United States v. Martin, 176 F. Supp. 262, 265 (S.D.N.Y. 1959); State v. Marshall, 234 Ore. $183,185,380$ P.2d 799,800 (1963).

46 This problem has been judicially recognized. See Culombe v. Connecticut, 367 U.S. 568, 574 (1961) (opinion of Frankfurter, J.); Ashcraft v. Tennessee, 322 U.S. 143, 149-53 (1944).

47 Cf. Mallory v. United States, 354 U.S. 449 (1957) ; McNabb v. United States, 318 U.S. 332 (1943). The $M c N a b b-M a l l o r y$ rule excludes from evidence statements made by defendants after they have been held in federal detention for more than a reasonable period of time. One rationale is to preclude the necessity of litigating what transpires in the detention room between the officers and the defendant. See id. at 344: "[The rule] aims to avoid all the evil implications of secret interrogation of persons accused of crime." 
than in that of other types of searches. In the entry situation the individual may extend a "come in" to an officer at his door without being aware that it is an officer who wants to enter. Likewise, the officer may not know the identity or the status of the individual who responds to his knock. On the other hand, an occupant is not likely to grant permission to search to an unidentified person, and, moreover, it is unlikely that anyone other than a policeman would be requesting to search a dwelling.

People v. Dent ${ }^{48}$ presented both identity problems. Two officers rang the bell of the defendant's house and either the defendant or her woman companion said, "Come in." The officers entered and immediately spied incriminating evidence. The court held the consent to enter ineffective on two grounds. First, it was not clear that the defendant had given her consent to enter, and no third party could effectively waive her constitutional rights. ${ }^{49}$ The alternative ground was that even if the defendant had given permission to enter, the officers at the door were required to disclose their identity. ${ }^{50}$

This first holding seems incorrect. If the purpose of an exclusionary rule is deterrence of undesirable police conduct, the issue should not be whether it was the defendant who consented, but rather, whether a policemen who has been given permission to enter by an unidentified voice should be required to ascertain the identity of the speaker.

In general courts have held that persons having a certain degree of control over a dwelling can consent to an invasion of that dwelling. ${ }^{51}$ Under this rule, a woman permanently living in a house would be entitled to consent to an entry, while a cleaning woman probably would not. Therefore, if an officer entered a house upon the invitation of a person such as a cleaning woman, he would be unconstitutionally infringing upon the privacy of the house. However, a person such as a cleaning woman would be unlikely to issue a general invitation to enter when she heard a knock on the door. Therefore, if an officer acts upon such an invitation without further inquiry, the chances that he would be infringing upon an individual's constitutional rights would be slight.

Moreover, to require an officer to ask an unseen person what interest he has in a house would seem quite impractical. The person might be too confused by the question to give a meaningful answer. Even if this were not the case, the officer might have considerable difficulty evaluating the reply, necessitating a further series of confusing inquiries. Furthermore, if the officer asked about the person's interest in the house, he would probably have to reveal that he was an officer. ${ }^{52}$ This might cause the occupant either to conceal evidence or to deny entry.

48371 Ill. 33, 19 N.E.2d 1020 (1939).

$49 \mathrm{Id}$. at 34,19 N.E.2d at 1021.

$50 I d$. at 36,19 N.E.2d at 1022 .

51 See text accompanying notes 60-78 infra.

52 This discussion assumes that a policeman is not constitutionally required to reveal his identity when he knocks on a suspect's door. For a discussion of this point, see text accompanying notes $56-57$ infra. 
On balance, the disadvantages of requiring an officer to inquire as to the identity of a voice which consents to an entry outweigh the slight additional fourth amendment protection which would accompany such a rule.

The alternative holding in Dent, that an officer must identify himself before there can be an effective consent to entry, ${ }^{53}$ can be profitably compared to the holding in People v. Hodson. ${ }^{54}$ There the court invalidated a consent to entry when a police officer had represented to the suspect that he was the hotel manager. To justify these decisions, it must be maintained that both entries obtained by deception and entries made upon a general invitation are likely to lead to infringements of the fourth amendment right of privacy.

When an individual allows a purported hotel manager to enter, he is choosing only to allow a hotel manager, not a police officer, to invade his privacy. There is no reason why an individual's fourth amendment rights cannot include the right to keep areas of his privacy free from invasion by particular classes of people, as well as from all invasions. The officer purporting to be a hotel manager does not give the individual a chance to effectively waive his right to exclude other classes of persons. Therefore, the Hodson result seems justifiable.

An occupant who issues a general invitation may in fact have intended the invitation for a specific person, such as an expected guest. In any event he clearly would not be contemplating the possibility that he is inviting a policeman to invade his privacy. However, this should not entitle a defendant such as in Dent to the same protection as that given to the defendant in Hodson. It was within the ability of the defendant in Dent to asertain the identity of his caller, and an unmanifested intention to grant a limited invasion of one's privacy should not be entitled to legal recognition.

Moreover, the Johnson v. Zerbst ${ }^{55}$ requirement of an intelligent waiver has no application here. The reason for furnishing a suspect with knowledge of his legal right to exclude, through the proposed rule of warning, is to provide the suspect with the basis for a meaningful choice. ${ }^{56}$ The fact that the defendant in Dent had no knowledge that a policeman was knocking does not import a lack of acceptable basis for choice. The fact that a caller knocks indicates his intent to comply with the desires of the inhabitant. The defendant's knowledge that he could exclude the caller should satisfy the constitutional requirement of a "knowing waiver."

Supreme Court decisions in related areas of criminal procedure justify distinguishing cases such as Hodson from those such as Dent. Gouled v.

53 But see Simmons v. Bomar, 230 F. Supp. 226 (M.D. Tenn. 1964).

5437 Cal. Rptr. 575 (Dist. Ct. App. 1964). The suspect opened the door to admit the "hotel manager" and later consented to a search. The court held the consent to search invalid because of the "improper" entry. However, the discussion here assumes the opening of the door to have been a consent to entry. But cf. Chieftain Pontiac Corp. v. Julian, 209 F.2d 657 (1st Cir. 1954) (dictum) (consent to search after a fraudulent misrepresentation held valid).

55304 U.S. 458 (1938).

56 See text accompanying notes 33-38 supra. 
United States ${ }^{57}$ established the rule that evidence obtained after entry by trick or stealth is inadmissible. In On Lee v. United States, ${ }^{58}$ an old acquaintance of the defendant who had become a police officer entered. the suspect's laundry and, without revealing his new occupation, engaged the suspect in conversation. The Court held admissible incriminating statements made by defendant and recorded through a microphone concealed on the agent's person. In Lopez $v$. United States, ${ }^{59}$ the defendant invited a revenue agent to meet with him, suggesting that he would offer a bribe. The agent kept the appointment and did not tell the defendant that he had no interest in a bribe. The Court held admissible statements recorded by the agent during his discussion with the defendant. In Gouled the officers obtained evidence through affirmative deceit. In On Lee and Lopez the officers did not use such deceit to help them obtain evidence; but neither did they voluntarily explain to the suspects their intentions, although had they done so, the suspects undoubtedly would not have conversed so freely. Thus the Court seems to exclude evidence obtained by an officer's affirmatively deceitful action, but admits evidence that is obtained by an officer who does not volunteer facts to a suspect.

\section{Third Party Consent to a Search}

\section{A. Searches of Drellings}

\section{The Constitutional Foundation}

In Stoner v. California, ${ }^{60}$ a hotel clerk allowed the police to search a guest's room. In holding that the clerk could not consent to this search, the Supreme Court stated: "It is important to bear in mind that it was. the petitioner's constitutional right which was at stake here, and not the night clerk's nor the hotel's. It was a right, therefore, which only the petitioner could waive by word or deed, either directly or through an agent." 61 This statement implies that the fourth amendment right to be secure in the home guarantees that no evidence in a dwelling can be constitutionally seized unless either the person against whom the evidence is to be used, or someone to whom he has delegated authority to consent to a search, chooses to allow the search. ${ }^{62}$ A suspect would in practice rarely make an express delegation of authority to a third party to consent to a search which

57255 U.S. 298 (1921). Gouled was limited to its facts by Olmstead v. United States, 277 U.S. 438, 463 (1928).

58343 U.S. 747 (1952).

50373 U.S. 427 (1963).

60376 U.S. 483 (1964).

61 Id. at 489.

62 For an example of this approach, see Kelley v. State, 184 Tenn. 143, 197 S.W.2d 545 (1946), in which the court disallowed a wife's consent to a search of her husband's house because she was angry with him at the time and, therefore, could not then have been acting as his agent. 
would be likely to reveal incriminating evidence. Therefore, Stoner's approach would allow third party consents only through use of the fiction that the third party had been given implied authority to consent. ${ }^{63}$

At the time of passage of the fourth amendment, the chief evil our founders were seeking to remedy was the uninvited intrusions into private houses by customs officials. ${ }^{64}$ The amendment was adopted to restrain these officials from invading "homes, papers, and personal effects" with only a general warrant or with no warrant at all.65 "Papers and personal effects" connote belongings which are the exclusive property of one individual, thus seeming to insure protection of a personal sphere of privacy. On the other hand, a dwelling can be a "home" to several people. Therefore, "secure in their homes" would seem to have been devised to protect a property right. If so, any person having sufficient control over the property should be able to decide whether or not the property right should be waived. Therefore, despite the Stoner dictum, any person having a suffcient level of control over a dwelling should be able to consent to a search of it.

\section{The Test of Control}

Courts applying the control test generally find that the third party can consent if he has, in a practical sense, free access to the dwelling and substantial freedom to do what he wishes within the dwelling. ${ }^{68}$ Three typical situations in which this test is appropriate are when a wife consents to a search which tends to incriminate her husband, when a landlord consents to a search which tends to incriminate his tenant, and when an employee consents to a search which tends to incriminate his employer.

In United States v. Sergio ${ }^{67}$ federal agents, smelling fermenting mash coming from a house in a residential area, knocked at the door. The defendant's wife, on answering, was told by the agents of their knowledge of the still's existence and was asked about the smell. She denied knowledge, but said that they were welcome to search the house. The court held this consent effective. Because the wife had complete freedom with respect to

63 See, e.g., Davis v. United States, 327 F.2d 301 (9th Cir. 1964), in which the court held admissible evidence obtained after officers were granted entry into the defendant's house by an eight year old girl. The court said: "From all the evidence before it, the trial court was entitled to conclude that her opening the door and invitation to enter were not . . . unauthorized acts." Id. at 303.

64 See Lasson, The History and Development of the Fourth Amendment to the United States Coustitution, 55 JoHNS HOPKINS UNIVERSTrY STUDIES IN HISTORICAL and Political Studies 211, 261-88 (1937).

65 See $i d$. at 289-315.

60 Of course, the third party should be of sufficient mentality and maturity to be able to know what he is doing when he consents to a search. See Gilliland v. Commonwealth, $224 \mathrm{Ky} .453,6$ S.W.2d 467 (1928) (evidence inadmissible against two sons when consent given by senile father). But see Davis v. United States, 327 F.2d 301 (9th Cir. 1964) (evidence admissible where obtained by officers allowed to enter house by defendant's eight year old daughter).

6721 F. Supp. 553 (E.D.N.Y. 1937). 
the premises and was at the time in charge of the premises, the court's decision is clearly correct. $^{\text {e8 }}$

In Stein v. United States, ${ }^{69}$ defendant and a woman were living together as if man and wife. A home was purchased with the defendant's money, but title was taken in the names of both defendant and his mistress. Subsequently, they had a violent disagreement, and both left the house to live with separate friends, but the defendant retained the key. His mistress later consented to a search of the house. The court held this consent valid on the ground that the joint ownership of the house gave her sufficient control over it to extend the invitation.

In this case the woman had left the house, had no immediate means of reentering it, and was clearly antagonistic towards the man with whom she had been living. All these facts would tend to make it appear to an officer that she lacked sufficient control over the house to consent to a search. On the other hand, if the officer knew that the woman had joint title to the house, ${ }^{70}$ he would be aware that she had a legal right to return thereto. This alone does not justify the court's decision, because the woman's bare legal right did not give her control over the house in any practical sense. ${ }^{71}$ However, if the officer also knew that the defendant had left the house, ${ }^{72}$ this would tend to justify the court's holding. Control over a dwelling is not a concept measurable in absolute terms. A person with little control over a dwelling should not be allowed to consent to a search of it where another person has a high degree of control. However, when no one has a high degree of control over a dwelling, a person with little control should be able to consent to a search. Relative to the other interests in the dwelling, his degree of control is significant. ${ }^{73}$ In Stein the woman apparently had a small degree of control over the dwelling, while the man's control was slightly greater. Whether this woman had sufficient relative

68 Accord, Roberts v. United States, 332 F.2d 892 (8th Cir. 1964); United States v. Heine, 149 F.2d 485 (2d Cir.) (by implication), cert. denied, 325 U.S. 885 (1945). Contra, United States v. Rykowski, 267 Fed. 866 (S.D. Ohio 1920). Compare Jones v. State, 83 Okla. Crim. 358, 177 P.2d 148 (1946) (husband's consent binds wife).

69166 F.2d 851 (9th Cir.), cert. denied, 334 U.S. 844 (1948).

70 There is no indication whether or not the officers were cognizant of this fact.

71 See Jones v. United States, 362 U.S. 257, 266 (1960) :

[I]t is unnecessary and ill-advised to import into the law surrounding the constitutional right to be free from unreasonable searches and seizures subtle distinctions, developed and refined by the common law in evolving the body of private property law which, more than almost any other branch of law, has been shaped by distinctions whose validity is largely historical.

${ }^{72}$ There is similarly no indication whether or not the officers were cognizant of this fact.

73 This rationale satisfactorily explains some cases which are difficult to justify under any other third party consent to search theory. See Cutting v. United States, 169 F.2d 951 (9th Cir. 1948) (consent to search by neighbor valid where defendant resided in another part of city); Reszutek v. United States, 147 F.2d 142 (2d Cir. 1945) (superintendent of house can validly consent to search of it when material in it tended to incriminate the house owner who did not have a possessory interest in the house). Compare Idol v. State, 223 Ind. 307, 119 N.E.2d 428 (1954) (superintendent cannot give valid consent to search of fraternity garage where defendant kept his car). 
control over the dwelling to consent to a search poses such a close question that the court's determination is neither untenable nor clearly correct.

In Chapman v. United States, ${ }^{74}$ a landlord smelled mash at the premises of a tenant. He called the police, and together they forced their way into the dwelling. The Supreme Court held that even though the landlord was entitled under state law to enter for the purpose of viewing waste, he could not enter with police officers for the purpose of conducting a search. ${ }^{75}$ In Woodard $v$. United States, ${ }^{76}$ an elderly lady took her grand-nephew and another boy into her house as nonpaying boarders. While cleaning their room, she saw some incriminating evidence and called the police. The lady was held to be able to consent to a search.77 Unlike the landlord in Chapman, this woman manifestly had free access to the boys' room. Therefore, both Chapman and Woodard would seem to have been correctly decided. ${ }^{78}$

In People v. Carswell, ${ }^{\text {,9 }}$ the police knocked at the suspect's door and were admitted by a man who was painting the premises. The court held that the painter could not effectively consent to the search. In People $v$. Misquez, ${ }^{80}$ the defendant and his mistress were in police custody. The babysitter for the defendant's children was also at the police station. A police officer obtained access to their apartment by inducing the babysitter to give him a key. The court held that the babysitter could consent to a search. Unlike the painter, the babysitter, by virtue of her posession of a key, would seem to the police to have substantial freedom to enter and leave the apartment as she pleased. Therefore, both the Carswell and Misquez decisions are justifiable.

\section{B. The Individual's Personal Privacy}

That part of the fourth amendment provision specifying that individuals should be "secure in their . . . papers and personal effects" seems to define an area of personal privacy peculiar to the individual, which should not be invaded by an officer without a warrant unless the individual personally consents.

In Bielicki v. Superior Court, 81 the owner of an amusement park authorized police to install a pipe which would enable them to see any homosexual activity taking place in two pay toilets. The court held the consent of the park owner ineffective on the ground that the person occupying the

74365 U.S. 610 (1961).

$75 \mathrm{Id}$. at 616 (alternative holding).

76254 F.2d 312 (D.C. Cir.), cert. denied, 357 U.S. 930 (1958).

77 But see Burge v. United States, 333 F.2d 210 (9th Cir. 1964) (occupant of an apartment can not consent to a search which will tend to incriminate a guest staying in her apartment).

78 See also Driskill v. United States, 281 Fed. 146 (9th Cir. 1922) (lessee can consent to search of garage when lessor has right to store his things in the garage).

79149 Cal. App. 2d 395, 308 P.2d 852 (Dist. Ct. App. 1957).

80152 Cal. App. 2d 471, 131 P.2d 206 (Dist. Ct. App. 1957).

81157 Cal. 2d 602, 371 P.2d 288, 21 Cal. Rptr. 552 (1962). 
stall had a personal right of privacy. ${ }^{82}$ In Blok $v$. United States, ${ }^{83}$ defendant's official supervisor consented to a search of a desk which was Government property assigned to the defendant. In holding the consent to search invalid, the court said that the supervisor could have looked for a pair of scissors in the desk, but could not consent to have policemen look therein for stolen property. ${ }^{84}$ Bielicki indicates that an individual's area of personal privacy is that which he would reasonably expect to be left undisturbed by others. Blok shows that an area may be nonprivate with respect to some infringements, but still private with respect to others.

An individual may by his actions relinquish his fourth amendment protection over his personal belongings. In Sartain v. United States, ${ }^{85}$ the suspect delivered his brief case together with a key to a friend who turned them over to the police. The court held the friend's consent to the search valid because he had full access to the bag. In Eldridge v. United States, ${ }^{86}$ the suspect lent his car to a friend. After the friend consented to a search of the car, incriminating evidence was found in the trunk. In holding that the friend's consent to the search was effective, the court emphasized that at the time of the consent, the friend was using the car as his own. ${ }^{87}$

In both of these cases, the suspect gave a third party complete freedom to use his personal belongings. Under such circumstances the suspect seems affirmatively to be taking the risk that the third party will show his personal belongings to others. Therefore, it is not unreasonable to conclude that in these cases the suspect has impliedly given the third party authority to waive his own personal right of privacy. ${ }^{88}$

A more difficult problem is posed when a suspect puts his personal effects in a container and leaves the container on the property of a third party. In Holzhey $v$. United States, ${ }^{89}$ the suspect's daughter and son-inlaw gave the police permission to search their premises. When the police approached a locked cabinet, the daughter and son-in-law made statements which should have alerted the police to the possibility that the cabinet did not belong to them. Nevertheless, the police searched the cabinet. The

82 Compare Britt v. Superior Court, 58 Cal. 2d 469, 374 P.2d 817, 24 Cal. Rptr. 849 (1962) (evidence inadmissible when police observe homosexual activities in closed stall of nonpay toilets through pipe already installed); People v. Norton, 209 Cal. App. 2d 173, 25 Cal. Rptr. 676 (Dist. Ct. App. 1962) (evidence admissible when observed in open stall by officers peering through holes in urinal across from the stall). See generally Comment, 63 CoLUM. L. REv. 955 (1963).

83188 F.2d 1019 (D.C. Cir. 1951).

84 Id. at 1021. Contra, United States v. Ebeling, 146 F.2d 254, 257 (2d Cir. 1944) (dictum).

85303 F.2d 859 (9th Cir.), cert. denied, 371 U.S. 894 (1962).

86302 F.2d 463 (4th Cir. 1962).

$87 I d$. at 466 . The dissent stressed the brief period for which the third party was to use the car and the limited purpose for which he could use it. Id. at 467. However, in terms of effective police deterrence, the situation as it would appear at the time of the consent would be the crucial issue. At that time, the third party obviously had effective control of the car.

88 Compare text accompanying note 62 supra.

89223 F.2d 823 (5th Cir. 1955). 
court held the third party consent invalid because the police had a duty at least to inquire whether or not an individual's personal effects were being invaded.

In United States $v$. Rees, ${ }^{90}$ police officers received permission from the suspect's mother and father to search their house. In a crawl space they found what seemed to be a suit case tagged with the name and phone number of Dennis J. Werber, a third party. Defendant's father gave permission to open the suitcase. The court held the father's consent effective. ${ }^{91}$ It seems difficult to distinguish validly this case from Holshey. Appearances were that the bag belonged exclusively to Dennis J. Werber. Therefore, because Werber was not asked whether the bag could be opened, the evidence taken from the bag should have been excluded from trial.

The Rees case aptly demonstrates that to deter effectively police conduct which may lead to fourth amendment violations, evidence constitutionally obtained may have to be excluded. After the police opened the bag, they questioned Dennis J. Werber. From the answers he gave, it seemed that the bag was his, and that he would have consented to an original search of it. ${ }^{22}$ Nevertheless, the evidence obtained from the bag should have been excluded to deter policemen from opening private bags before obtaining permission from a person in Werber's position.

\section{CoNCLUSION}

Modern criminal process has in many contexts recognized that a reasonable safeguard against the blunder of the constable is freedom for the individual whose rights have been invaded. This attitude similarly should be embodied in concrete rules of law which will deter police conduct leading to consents to waive fourth amendment rights given either for unacceptable reasons or by unacceptable individuals.

\section{Welsh S. White}

90193 F. Supp. 849 (D. Md. 1961).

91 Cf. Abel v. United States, 362 U.S. 217, 241 (1960) ; United States v. Minker, 312 F.2d 632 (3d Cir. 1962), cert. denied, 372 U.S. 953 (1963); Burton v. United States, 272 F.2d 473 (9th Cir. 1959), cert. denied, 362 U.S. 951 (1960). In these cases searches were permitted because the suspect had abandoned the evidence.

82193 F. Supp. at 853. 